\title{
Limnological profile of a semi-urban lentic ecosystem of Kashmir with special reference to the macroinvertebrate community of Anchar Lake
}

\author{
Mohd Yaseen Gudoo ${ }^{1 *}$, Mohammad Farooq Mir², Anuja Gupta ${ }^{3}$ \\ ${ }^{1}$ Department of Zoology Barkatullah University Bhopal (M.P), India \\ ${ }^{2}$ Hydrobiology Research Laboratory, S.P College, Cluster University Srinagar, Kashmir, India \\ ${ }^{3}$ Department of Zoology Government MVM, Bhopal (M.P), India \\ ${ }^{*}$ Corresponding author, E-mail: yaseenzoologica@gmail.com
}

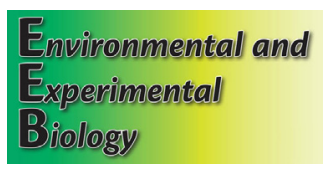

ISSN 2255-9582

UNIVERSITY OF LATVIA

\begin{abstract}
The current study was undertaken to investigate the macroinvertebrate community and physico-chemical features of Anchar Lake of Kashmir. Sampling of macroinvertebrates was performed using a handmade D-frame net and Ekman dredge, while physico-chemical analysis was conducted according the standards methods of the American Public Health Association. A total of 20 macroinvertebrate taxa were recorded belong to phylum Annelida, Arthropoda and Mollusca, representing six classes, 13 orders and 18 families. The mean value of several biotic indices was computed: 2.31 for Shannon-Wiener index, 0.87 for Simpson's index, 1.58 for Margalef's index and 0.17 for evenness index. Water analysis revealed that the lake was eutrophic, alkaline, highly productive, and had hard water that was organically polluted. The quality of water, organic rich bottom sediment, density and architecture of macrophytes were found to be vital factors determining the abundance, diversity and patterns in distribution of macroinvertebrate fauna of the lake. Further, anthropogenic pressure in the lake catchment area was observed as potential force behind the current ecological conditions of lake. The study concluded that the lake is under extreme anthropogenic stress and is victim of severe pollution, therefore requiring immediate restoration measures.
\end{abstract}

Key words: anthropogenic pressure, diversity, macroinvertebrates, pollution, water quality.

Abbreviations: BOD, biological oxygen demand; DO, dissolved oxygen; TDS, total dissolved solids.

\section{Introduction}

Aquatic ecosystems are precious and irreplaceable not only as a resource for domestic, agricultural, industrial, economic and other needs (Shokri 2014), but also as a system acting as an elixir of life and harbouring diverse forms of flora and fauna, and balancing our global ecosystem and maintaining the aesthetic value of our beautiful planet (Gudoo et al. 2020). Among several types of freshwater ecosystems, lentic ecosystems are a main focus of current scientific studies due to their rich biological wealth (Gudoo 2019). Among the enormously huge number of aquatic biota inhabiting aquatic ecosystems, invertebrates occupy a unique position from the ecological point of view. Invertebrates encompass a wide range of organisms differing in shape, size, morphological characteristics and phylogenetic relationships. Diversity among invertebrates does not occur only in genotypic and phenotypic characters, but also in their habit, habitat, species number as well as in their distribution patterns. Invertebrates have adapted practically to every ecological niche, ranging from deep oceans to small pools (Kotpal 2018-2019).
Despite of having boundless ecological significance, it is quite unfortunate that currently aquatic ecosystems are brutally exploited and degraded globally at a rate faster than ever identified in the past. Water bodies are under great threat to influx of variety of pollutants (Shokri 2014). Among the various impacts, urbanization is one of the major factors affecting the ecology of aquatic ecosystems (Paul, Meyer, 2001). The major problems accompanying urbanization include increasing rate of sedimentation, release of bulk of domestic sewage and dumping of lethal solid wastes into water body, which worsens the overall environmental condition of aquatic ecosystems (Baur, Pringle 2000). Increasing sediment loads in an aquatic ecosystem negatively affect its physico-chemical and biological components. Excessive sedimentation reduces light penetration and interferes with various crucial life processes like nutrition, reproduction and other life processes of bottom dwelling organisms, including benthic macroinvertebrate communities (Mangun 1989). Histological studies of macroinvertebrate fauna in urban areas has revealed higher concentration of toxic metals in their tissues. Toxic metal concentration decreases the 
abundance and alters the species composition of aquatic ecosystems (Gundacker 2000). Higher concentration of nitrogen- and phosphorous- rich fertilizers, which find their way in water bodies, are also responsible for destabilization of aquatic ecosystems (Burton et al. 1977).

Multiple efforts have been made nationwide from time to time to minimize the impacts to water bodies, for instance installation of sewage treatment plants to minimize direct release of various pollutants (Jones, Clark 1987). However, under certain specific circumstances these approaches are unable to work with better efficiency (Paul, Meyer 2001). To lessen anthropogenic induced stress to precious water bodies, efficient workable eco-conservation approaches must be employed. In order to obtain better results in ecorestoration of aquatic ecosystems, a profound understanding of the ecological status of water bodies is required. The evaluation of the ecological status of aquatic ecosystems merely by employing traditional physicochemical approach seems insufficient and scientifically unsound (Karr 1995). Current investigations, in addition to the physico-chemical approach, employs the biological approach (biomonitoring), as well as consider the response of living organisms to different and slight deviations in biotic as well as abiotic components of water bodies (Tate, Heiny 1995).

Among diverse forms of life in aquatic ecosystems, invertebrates have been considered as model organisms to investigate the impact of undesirable anthropogenic activities on water bodies (Duda et al. 1982; Johnson 1993). They are of immense ecological significance from a scientific point of view due to their unique ability to respond to any slight change in any physcico-chemical or biological component of an aquatic ecosystem. The composition of a macroinvertebrate community is closely linked to overall conditions in water bodies. The benthic macroinvertebrate community of a particular aquatic habitat is crucial in determining the pollution status of a water body and is therefore an important criterion for ecological classification of lakes (Malik, Ali 2012). Further, the reason behind the application of benthic macroinvertebrate fauna in biomonitoring is that diverse macroinvertebrate taxa possess different ranges of tolerance to pollution (Aura et al. 2011; Shokri 2014). Diverse stressors upset community diversity (Herring et al. 2006). A decline in abundance of pollution sensitive taxa and their diversity followed by their replacement by pollution resistant taxa was observed to take place as a result of influx of urban flows and waste water from agricultural fields (Moretti, Callisto 2005; Song et al. 2008). The study of the diversity of aquatic macroinvertebrates and their multiple roles as tools for determining the quality of an aquatic ecosystem might have few difficulties, but despite these difficulties, many studies have documented the efficiency and validity of the biological approach by employing macroinvertebrates to evaluate the impact of undesirable anthropogenic activities on aquatic ecosystems (Shokri 2014).

The objectives of the current paper were aimed to study the macroinvertebrate fauna, physico-chemical profile and the factors responsible for the present scenario of lake, so that appropriate measures could be undertaken towards the restoration of lake and its protection from further deterioration.

\section{Materials and methods}

\section{Study area}

The present survey was conducted in Anchar Lake, a high altitude semi-urban lake situated about $12 \mathrm{~km}$ to the North West of Srinagar city in the beautiful valley of Kashmir at an altitude of 1584 meter above sea level within the geographical coordinates of $34^{\circ} 20^{\prime}$ to $34^{\circ} 36^{\prime} \mathrm{N}$ and $74^{\circ} 82^{\prime}$ to $74^{\circ} 85^{\prime} \mathrm{E}$. The lake is fluviatile in origin. Sind River flows into the lake from its Northern side and serves as a key source of glacial water and silt loading. The lake water outflows into river Jhelum from its Western side through Sangam village. The lake also receives agricultural runoff and domestic sewage from the adjacent crop fields and nearby residential areas of Anchar, Buchpora, Umerhaira, Ahmadnagar and Pandach, which raise the nutrient levels of the lake. Also, Sheri-Kashmir Institute of Medical Sciences discharges its toxic wastes into Anchar Lake. As a result of substantial anthropogenic pressure, the quality of the lake is deteriorating ceaselessly and is posing a danger not only to the biodiversity of lake but also to people who directly or indirectly depend on the lake for aquatic foods like fish and the crop Nadru (Nelumbo nucifera) (Bhat et al. 2001; Kak 2012; Ahanger 2014).

\section{Description of study sites}

Site A 1 , located on the Northern side of lake, receives glacial water and silt loads from the River Sind (Fig. 1). Site A2 site was located at the center of lake with Jinab sahib shrine and Anchar village on its Eastern side and Sangam outlet on its western side. This site receives the largest inputs of domestic sewage and organic waste released from human settlement areas. Site A3 was located at the exit of the lake on it western side near the dam locally known as Kedar sahib dam. At this site, water outflows from Anchar Lake into river Jhelum via Sangam village.

\section{Collection and analysis of water samples}

Sampling was performed on a monthly basis for a period of two years stretched from March 2016 to February 2018. Water samples were collected in iodine treated polyethylene plastic bottles. Physico-chemical analysis was performed according to standard methods of APHA, 2004. Air and water temperature, transparency, depth, dissolved oxygen (DO), $\mathrm{pH}$ and free carbon dioxide were measured in the field during water sample collection, while electrical conductivity, total dissolved solids (TDS) total alkalinity, 

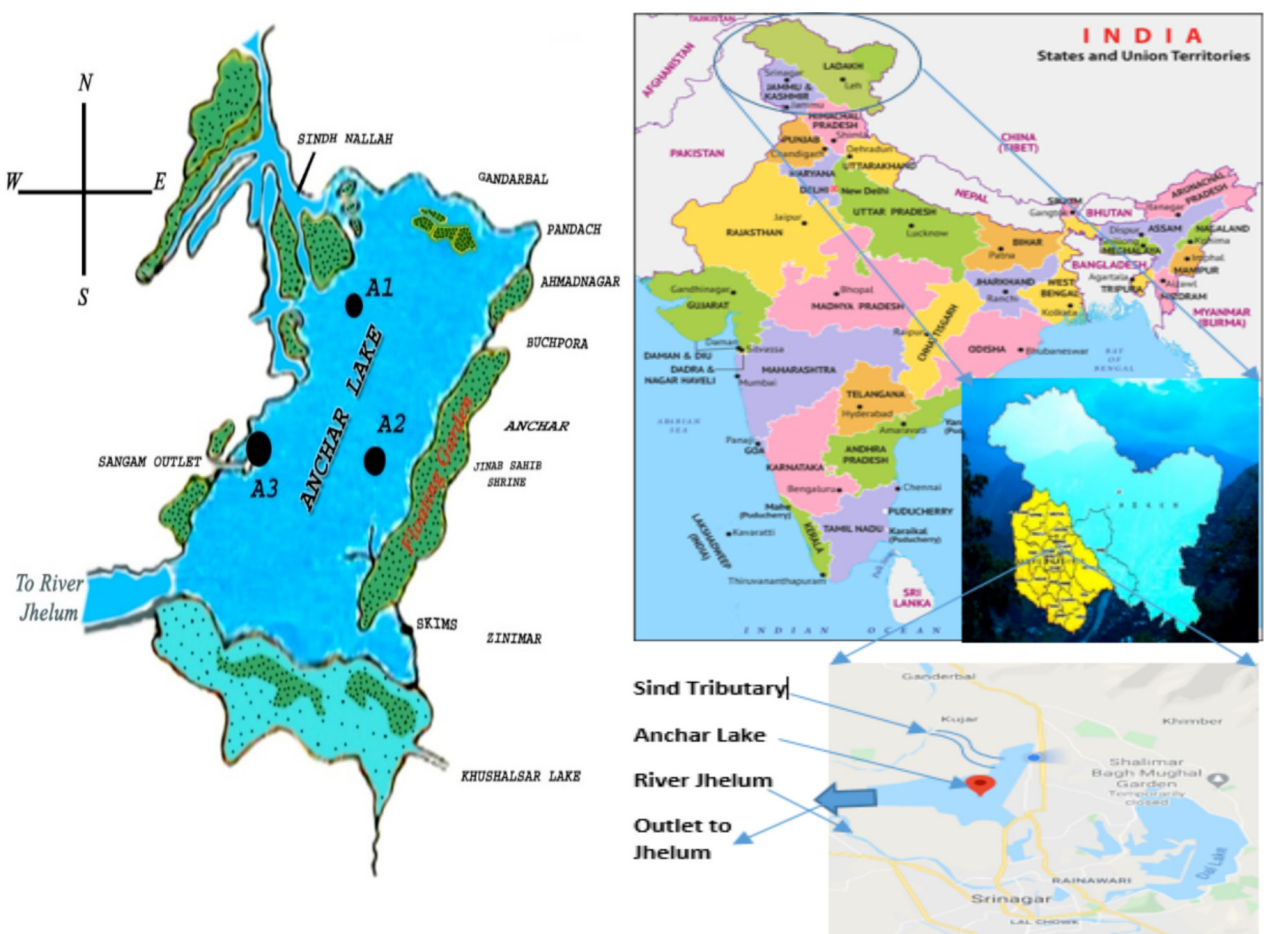

Fig. 1. Location of the study area in India, Jammu and Kasmir, in Kashmir Valley, and study sites in Anchar Lake.

total hardness, biological oxygen demand (BOD), and concentration of chloride, nitrate, total phosphorous, ammonia and iron were analyzed at the hydrobiology research laboratory in S.P. College, Srinagar.

\section{Collection and preservation of macroinvertebrates}

Macroinvertebrates sampling was executed on a monthly basis from March 2016 to February 2018 using a D-frame net (mesh width $0.5 \mathrm{~mm}$ ) and Ekman dredge, each with dimensions of $15 \times 15 \mathrm{~cm}$. D-frame net sweeps in a forward direction were performed to collect the macroinvertebrates residing the water column present between bottom and surface (Hoffsten, Malmqvist 2000; Kovalenko et al. 2014) while an Ekman dredge was used to collect benthic samples (Fishar, William 2006). At each site, samples were taken in triplicate and then pooled together. The samples were properly mixed with water and were sieved through a sieve net (mesh width $250 \mu \mathrm{m}$ ) to remove fine particles (Kovalenko et al. 2014). The organisms retained in the sieve were sorted manually using forceps and brushes and were preserved in clean plastic bottles filled with $4 \%$ formalin and $70 \%$ alcohol, depending on the type of organism to be preserved. Soft-bodied organisms were preserved in $70 \%$ alcohol while shelled organisms like molluscs in $4 \%$ formalin (Borror et al. 1976).

\section{Qualitative and quantitative study of macroinvertebrates}

For qualitative examination, preserved samples of macroinvertebrate taxa were identified in the laboratory under a stereomicroscope at 10 to $40 \times$ magnification to the lowest possible taxonomic level according to standard taxonomic works of Edmondson (1959), Pennak (1978) and Adoni (1985). For quantitative investigation, numbers of individuals were counted by macroinvertebrate taxa. The density of the macroinvertebrate fauna was calculated by using the formula (Welch, 1948):

$$
N=(O / A \times S) \times 10000,
$$

where $N$ is a number of organisms per $\mathrm{m}^{2}, O$ is a number of organisms counted, $A$ is an area of sampler in $\mathrm{m}^{2}, S$ is the number samples taken at each site.

\section{Biological indices}

Biological indices were used for evaluating the diversity and richness of macroinvertebrates. Shannon-Wiener diversity index $(H)$ was calculated as

$$
H=-\sum_{\mathrm{I}=1}^{\mathrm{S}}\left[\left(p_{i}\right) \times \ln \left(p_{i}\right)\right]
$$

where $p_{i}$ (fraction of the entire population made up of species $i)=n_{i} / N\left(n_{i}\right.$ is the number of individuals found for species $i$ and $N$ is the total number of individuals in the community), $S$ is the number of species encountered, and $\Sigma$ is a sum from species $i$ to species $s$.

Simpson's diversity index $(1-D)$ was calculated as

$$
1-D=1-\sum n(n-1) / N(N-1) \text {, }
$$

where $n$ is a number of individuals of each species, and $N$ is the total number of individuals of all species.

Margalef's richness index was calculated as

$$
D=(S-1) / \ln (N) \text {, }
$$

where $S$ is the total number of species, and $N$ is the total number of individuals in a sample. 
Species evenness was calculated as

$$
E=H / \ln (S)
$$

where $H$ is Shannon-Wiener diversity index, and $S$ is the number of species recorded.

\section{Results and discussion}

\section{Physicochemical analysis}

Physicochemical features of Anchar Lake were monitored on monthly basis for a period of two years at three different sites. The results of the physicochemical analysis of Anchar Lake are summarized in Table 1.

During the present study, the air temperature ranged from $3.2{ }^{\circ} \mathrm{C}$ in January 2017 at site $\mathrm{A} 1$ to $23.2{ }^{\circ} \mathrm{C}$ in June 2017 at site $\mathrm{A} 3$, with an average value of $12.97 \pm 7.58^{\circ} \mathrm{C}$. The water temperature fluctuated from $2.1^{\circ} \mathrm{C}$ in February 2018 at site A1 to $21.9^{\circ} \mathrm{C}$ in July 2016 at site A2 and A3 with a mean value of $11.58 \pm 7.44^{\circ} \mathrm{C}$. The variation in air and water temperature followed a seasonal climatic pattern, with a maximum during summer and minimum during winter throughout the study period, which may be ascribed to high intensity and longer bright sunlight duration during summer and vice-versa (Zuber 2007; Sawhney 2008).

Water depth varied from $1.14 \mathrm{~m}$ in September 2016 at site A1 to $1.85 \mathrm{~m}$ in April 2017 at site A2 with a mean depth of $1.38 \pm 0.28 \mathrm{~m}$. The maximum depth in the Anchar Lake was observed in winter, which may be attributed to higher precipitation, increased flow of glacial waters into the lake and low rate of evaporation during winters as shown by Sawhney (2008) and Ahanger (2014). Tehseen et al. (2018) observed that depth in Anchar Lake fluctuates from 0.95 to $1.7 \mathrm{~m}$ with a mean value of $1.1 \mathrm{~m}$.

Table 1. Physicochemical analysis of Anchar Lake at three sites
Water transparency ranged from $0.11 \mathrm{~m}$ in July 2016 at sites A1 and A3 and July 2017 at site $\mathrm{A} 2$ to $0.33 \mathrm{~m}$ in December 2017 at site A1 with a mean value of $0.2 \pm$ $0.05 \mathrm{~m}$. Transparency was at maximum during winter. The winter maxima may be due to lower turbidity due to presence of less suspended organic matter, which settlse to the bottom because of slow movement of water during winter (Shinde et al. 2010) The summer minima may be explained by higher silt loading and an increased rate of discharge of domestic and municipal sewage in the lake during summer, as observed by Singh (2004), Ayoade et al. (2006), and Jayabhaye et al. (2008). Tehseen et al. (2018) recorded that transparency in Anchar Lake fluctuates from 0.5 to $0.8 \mathrm{~m}$ with a mean value of $0.5 \mathrm{~m}$

The $\mathrm{pH}$ of water ranged from 7.1 in January 2018 at site A1 to 9.2 in July 2017 at site A2 with an average value of $8.09 \pm 0.62$. The observed variation in $\mathrm{pH}$ clearly followed a seasonal trend. It was higher in summer and lower during winter, due to promoted photosynthesis at high temperature and a prolonged photoperiod during summer (Egborge 1994; Akthar et al. 2015). The pH also indicated the alkaliphilous nature of the lake within the range described by Venkateshwarlu (1983), which may be due to sewage discharge from immediate catchments into the lake (Umerfaruq, Solanki 2015). Tehseen et al. (2018) recorded that $\mathrm{pH}$ in Anchar Lake fluctuated from 7.8 to 8.2 with a mean value of 7.9. Bashir et al. (2017) found that $\mathrm{pH}$ in Anchar Lake fluctuated from 7.11 to 8.02 with a mean value of 7.56 and reported the lake waters as alkaliphilous.

Dissolved oxygen concentration fluctuated from 2.3 $\mathrm{mg} \mathrm{L}^{-1}$ in June 2017 at site $\mathrm{A} 2$ to $6.7 \mathrm{mg} \mathrm{L}^{-1}$ in January 2017 at site $\mathrm{A} 1$ with a mean value of $4.14 \pm 1.29 \mathrm{mg} \mathrm{L}^{-1}$.

\begin{tabular}{|c|c|c|c|c|c|c|c|}
\hline \multirow[t]{3}{*}{ Parameter (unit) } & \multicolumn{6}{|c|}{ Range of variation } & \multirow[t]{3}{*}{ Mean \pm SD } \\
\hline & \multicolumn{2}{|c|}{ Site A1 } & \multicolumn{2}{|c|}{ Site A2 } & \multicolumn{2}{|c|}{ Site A3 } & \\
\hline & Min. & Max. & Min. & Max. & Min. & Max. & \\
\hline Air temperature $\left({ }^{\circ} \mathrm{C}\right)$ & 3.2 & 22.7 & 3.3 & 22.8 & 3.3 & 23.2 & $12.97 \pm 7.58$ \\
\hline Water temperature $\left({ }^{\circ} \mathrm{C}\right)$ & 2.1 & 21.8 & 2.2 & 21.9 & 2.3 & 21.9 & $11.58 \pm 7.44$ \\
\hline Water depth (m) & 1.14 & 1.62 & 1.17 & 1.85 & 1.19 & 1.81 & $1.38 \pm 0.28$ \\
\hline Transparency (m) & 0.11 & 0.33 & 0.11 & 0.32 & 0.11 & 0.29 & $0.20 \pm 0.05$ \\
\hline $\mathrm{pH}$ & 7.1 & 8.9 & 7.1 & 9.2 & 7.2 & 8.7 & $8.09 \pm 0.62$ \\
\hline Dissolved oxygen $\left(\mathrm{mg} \mathrm{L}^{-1}\right)$ & 2.8 & 6.7 & 2.3 & 6.2 & 2.6 & 6.1 & $4.14 \pm 1.29$ \\
\hline Free $\mathrm{CO}_{2}\left(\mathrm{mg} \mathrm{L}^{-1}\right)$ & 7.1 & 33 & 8.4 & 34 & 8.1 & 34.1 & $16.53 \pm 9.19$ \\
\hline Electrical conductivity $\left(\mu \mathrm{S} \mathrm{cm}^{-1}\right)$ & 331 & 413 & 341 & 427 & 318 & 381 & $357.16 \pm 21.84$ \\
\hline Total alkalinity $\left(\mathrm{mg} \mathrm{L}^{-1}\right)$ & 189 & 321 & 207 & 347 & 202 & 325 & $251.93 \pm 37.31$ \\
\hline Total hardness $\left(\mathrm{mg} \mathrm{L}^{-1}\right)$ & 143 & 369 & 133 & 357 & 129 & 351 & $236.58 \pm 79.18$ \\
\hline Chloride concentration $\left(\mathrm{mg} \mathrm{L}^{-1}\right)$ & 15.5 & 30.1 & 19.3 & 37.2 & 18.4 & 34 & $25.09 \pm 5.06$ \\
\hline Total phosphorus $\left(\mu \mathrm{g} \mathrm{L}^{-1}\right)$ & 410 & 483 & 421 & 594 & 416 & 569 & $501.84 \pm 62.00$ \\
\hline Nitrate concentration $\left(\mu \mathrm{g} \mathrm{L}^{-1}\right)$ & 395 & 579 & 409 & 583 & 395 & 560 & $485.67 \pm 65.06$ \\
\hline $\operatorname{TDS}\left(\mathrm{mg} \mathrm{L}^{-1}\right)$ & 179 & 353 & 181 & 356 & 180 & 351 & $282.66 \pm 58.50$ \\
\hline $\mathrm{BOD}\left(\mathrm{mg} \mathrm{L}^{-1}\right)$ & 3.1 & 6.1 & 3.4 & 6.3 & 3.3 & 6.2 & $5.18 \pm 0.92$ \\
\hline Ammonia concentration $\left(\mathrm{mg} \mathrm{L}^{-1}\right)$ & 0.07 & 0.29 & 0.11 & 0.32 & 0.11 & 0.29 & $0.17 \pm 0.05$ \\
\hline Iron concentration $\left(\mathrm{mg} \mathrm{L}^{-1}\right)$ & 0.12 & 0.23 & 0.14 & 0.28 & 0.13 & 0.27 & $0.18 \pm 0.04$ \\
\hline
\end{tabular}


Higher dissolved oxygen was recorded during winter, spring and rainy season, due to low temperature and high transparency (Ali et al. 2015), decreased consumption rate of oxygen by decomposers (Ahanger 2014) during winter, higher aeration during rainfall (Ayoade et al. 2006) and increased photosynthesis during spring (Baig et al. 2010). Low dissolved oxygen concentration was recorded during summer season, which can be explained by high temperature (Ibrahim et al. 2006), increased consumption rate of oxygen by decomposers (Arimoro et al. 2007) and increased intensity of biological processes (Olomukoro 2008). Tehseen et al. (2018) reported that dissolved oxygen content in Anchar Lake fluctuated from 5 to $7.2 \mathrm{mg} \mathrm{L}^{-1}$ with a mean value of $5.4 \mathrm{mg} \mathrm{L}^{-1}$.

Free carbon dioxide concentration ranged between 7.1 $\mathrm{mg} \mathrm{L}^{-1}$ in March 2017 at site A1 to $34.1 \mathrm{mg} \mathrm{L}^{-1}$ in January 2018 at site $\mathrm{A} 3$ with a mean value of $16.53 \pm 9.19 \mathrm{mg} \mathrm{L}^{-1}$. It was higher in winter in association with low $\mathrm{pH}$ (Wetzel 2001), reduced macrophytic growth at low temperature (Zuber 2007) and reduced solubility of carbon dioxide in water at low temperature (Akhar et al. 2015). Low free carbon dioxide concentration was recorded in spring and summer, possibly due to increased photosynthesis (Aura et al. 2011) and abundant macrophytic growth (Akthar et al. 2015). The free carbon dioxide concentration also indicated the hard water type nature of the lake (Reid and Wood 1976). Bashir et al. (2017) reported that carbon dioxide content in Anchar Lake fluctuated from 6.25 to $14.2 \mathrm{mg}$ $\mathrm{L}^{-1}$ with a mean value of $10.13 \mathrm{mg} \mathrm{L}^{-1}$ and therefore that Anchar Lake was a hard water type water body.

Electrical conductivity fluctuated from $318 \mu \mathrm{S} \mathrm{cm}^{-1}$ in January 2017 at site A3 to $427 \mu \mathrm{S} \mathrm{cm}^{-1}$ at site A2 in July 2017 with a mean value of $357.16 \pm 21.84 \mu \mathrm{S} \mathrm{cm}^{-1}$. The observed variation in electrical conductivity clearly followed a seasonal trend. It was higher in summer and lower during winter and spring, which was caused by decomposition of nutrient rich organic matter in lake waters, and increasing organic and inorganic loading in lakes from immediate catchments during summer. Spring minima in electrical conductivity was a result of absorption of nutrients by macrophytes (Ahangar 2014; Sushil et al. 2014; Akthar et al. 2015). The conductivity also showed the eutrophic nature of the lake according to the classification of Olsen (1950) and Dunn (1954). Tehseen et al. (2018) reported that conductivity in Anchar Lake fluctuated from 297 to $510 \mu \mathrm{S} \mathrm{cm} \mathrm{cm}^{-1}$ with a mean value of $374 \mu \mathrm{S} \mathrm{cm} \mathrm{cm}^{-1}$. Bashir et al. (2017) found that electrical conductivity in Anchar Lake fluctuated from $152.3 \mu \mathrm{S} \mathrm{cm} \mathrm{cm}^{-1}$ to 380.2 with a mean value of $266.25 \mu \mathrm{S} \mathrm{cm}{ }^{-1}$.

Total alkalinity varied between $189 \mathrm{mg} \mathrm{L}^{-1}$ in April 2017 at site A1 to $347 \mathrm{mg} \mathrm{L}^{-1}$ in January 2018 at site A2 with a mean value of $251.93 \pm 37.31 \mathrm{mg} \mathrm{L}^{-1}$. The observed range for total alkalinity showed an increasing trend from summer to winter. High total alkalinity during summer can be attributed to a higher evaporation rate associated with elevated temperature (Naik 2015), increase in algal growth and higher decomposition rate (Chapman 1992). The low total alkalinity during spring and early summer can be caused by assimilation of nutrients at a higher rate by macrophytes and phytoplanktons to attain greater growth. The alkalinity also reflected the nutrient rich and productive nature of lake (Spence 1964; Sugunan 1989). Tehseen et al. (2018) reported that total alkalinity in Anchar Lake fluctuated from 158 to $191 \mathrm{mg} \mathrm{L}^{-1}$ with a mean value of $169 \mathrm{mg} \mathrm{L}^{-1}$.

Total hardness ranged from $129 \mathrm{mg} \mathrm{L}^{-1}$ in July 2016 at site $\mathrm{A} 3$ to $369 \mathrm{mg} \mathrm{L}^{-1}$ in February 2018 at site A1 with a mean value of $236.58 \pm 79.18 \mathrm{mg} \mathrm{L}^{-1}$. The upper values for total hardness were noted during winter, while lower values occurred in spring and summer. The minter maxima of total hardness results from less macrophytic and algal growth due to low temperature and increased solubility of ions at low temperature (Otsuki, Wetzel 1972). Spring and summer minima of total hardness can be a result of consumption of carbonates and bicarbonates by phytoplankton as a source of carbon, and reduced solubility of calcium ions at higher temperature (Bhat et al. 2013; Ahangar 2014). The total hardness also indicated the hard water type nature of the lake water (Sawyer 1960). Bashir et al. (2017) found that total hardness in Anchar Lake fluctuated from 106 to 303.2 $\mathrm{mg} \mathrm{L}^{-1}$ with a mean value of $204.6 \mathrm{mg} \mathrm{L}^{-1}$ and reported the hard water nature of the lake.

Chloride concentration in lake waters varied from 15.5 $\mathrm{mg} \mathrm{L}^{-1}$ in February 2017 at site A1 to $37.2 \mathrm{mg} \mathrm{L}^{-1}$ in June 2017 at site A2 with a mean value of $25.09 \pm 5.06 \mathrm{mg} \mathrm{L}^{-1}$. The chloride concentration was higher during summer and rainy season than in winter. The summer maxima can be due to elevated temperature (Korai et al. 2008), increased organic matter loads from mainly animal waste (Mahananda et al.2010) and increased rate of sewage loads into the lake from immediate catchments (Ahanger 2014). The winter chloride minima can be caused by decreased water temperature (Dalpatia 1998) and dilution of water by winter rains (Okeola et al. 2010). The high chloride concentration reflected the organically polluted nature of Anchar Lake (Ohle 1934). The high chloride concentration was related to organic pollution in Dal Lake (Jeelani, Kaur 2014). Bashir et al. (2017) reported that the chloride concentration in Anchar Lake ranged from 7.98 to 19.04 $\mathrm{mg} \mathrm{L}^{-1}$ with a mean value of $13.51 \mathrm{mg} \mathrm{L}^{-1}$ while as Tehseen et al. (2018) observed that the chloride concentration in Anchar Lake ranged from 23.5 to $42 \mathrm{mg} \mathrm{L}^{-1}$ with a mean value of $30.6 \mathrm{mg} \mathrm{L}^{-1}$. Both studies declared Anchar Lake as a victim of organic pollution.

Total phosphorus concentration in the lake ranged from $410 \mu \mathrm{g} \mathrm{L}^{-1}$ in January 2017 at site $\mathrm{A} 1$ to $594 \mu \mathrm{g} \mathrm{L}^{-1}$ in June 2017 at site A2 with a mean value of $501.84 \pm 62 \mu \mathrm{g} \mathrm{L}^{-1}$. Higher values for total phosphorus were recorded during summer and the rainy season, and lower values during winters and spring. The summer total phosphorous maxima 
may be due to increased agriculture runoff, higher input of domestic sewage (Gasim et al. 2006) and an elevated decomposition rate (Edokpayi et al. 2010; Patra et al. 2010; Shinde et al. 2010). The winter and spring total phosphorus minima can be caused by a low decomposition rate, low temperature and increased consumption of phosphorous by macrophytes, which grow vigorously during spring and summers causing a decline in phosphorous concentration towards winter. The total phosphorous concentration revealed the eutrophic nature of the lake (Vollenweider 1968). The eutrophic nature of Manasbal Lake in respect to phosphorus concentration was also shown (Naik et al.2015). Tehseen et al. (2018) observed that the total phosphorous concentration in Anchar lake ranged from 550 to $910 \mu \mathrm{g}$ $\mathrm{L}^{-1}$ with a mean value of $708 \mu \mathrm{g} \mathrm{L}^{-1}$ and described Anchar Lake as eutrophic.

Nitrate concentration varied from $395 \mu \mathrm{g} \mathrm{L}^{-1}$ in January 2017 at site A1 to $583 \mu \mathrm{g} \mathrm{L}{ }^{-1}$ in July 2016 at site A2 with a mean value of $485.67 \pm 65.06 \mu \mathrm{g} \mathrm{L}{ }^{-1}$. Higher concentration of nitrate was recorded during summer and the rainy season while the minimum concentration was during winter and spring. The summer maxima has been associated with agricultural waste (Gochhait 1991) and increased rate of decomposition of organic matter (Zuber 2007; Naik 2015). Winter and spring minima of nitrates may be due to a low decomposition rate, low temperature and increased utilization of nitrates by macrophytes, which grow vigorously during spring and summers, causing decrease in nitrate concentration towards winter. The high nitrate content reflects eutrophication in lake according to the classification of lakes on the basis of nitrate concentration (Vollenweider 1968). Tehseen et al. (2018) observed that nitrate nitrogen concentration in Anchar lake ranged from 558 to $641 \mu \mathrm{g} \mathrm{L}{ }^{-1}$ with a mean value of $574 \mu \mathrm{g} \mathrm{L} \mathrm{L}^{-1}$ and described the increasing trend of values in Anchar Lake as an indicator of a higher trophic level of the lake water.

TDS ranged between $179 \mathrm{mg} \mathrm{L}^{-1}$ in February 2017 at site A1 and $356 \mathrm{mg} \mathrm{L}^{-1}$ in June 2017 at site A2 with a mean value of $282.66 \pm 58.5 \mathrm{mg} \mathrm{L}^{-1}$. The higher TDS values recorded during summer and the rainy season were a result of increased input of wastes into the lake and emission of minerals due to a raised decomposition rate at higher temperature during summer, increased rate of surface runoff and leaching of substances from rocks into lake water during precipitation events. Lower TDS values were recorded during winter, which may be due to reduced waste input from immediate catchments and assimilation of salts and other ions by phytoplankton and macrophytes of lakes to attain maximum growth during spring and summers. The results obtained are in agreement with earlier findings (Korai et al. 2008; Singh et al. 2010; Ahanger 2014). Bashir et al. (2015) recorded that TDS concentration in Anchar Lake ranged from 98.2 to $400.2 \mathrm{mg} \mathrm{L}^{-1}$ with a mean value of $249.2 \mathrm{mg} \mathrm{L}^{-1}$ and described this range of TDS as a pollution indicator.
BOD values were observed to fluctuate from $3.1 \mathrm{mg}$ $\mathrm{L}^{-1}$ in January 2017 at site $\mathrm{A} 1$ to $6.3 \mathrm{mg} \mathrm{L}^{-1}$ in June 2017 at site $\mathrm{A} 2$ with a mean value of $5.18 \pm 0.92 \mathrm{mg} \mathrm{L}^{-1}$. It was evident that the BOD showed a steady increase from winter to summer. The summer BOD maxima can be due to high temperature casuing higher rate of microbial activity and decomposition (Singh et al. 2002), increase in agricultural runoff (Sachidanandmurthy, Yajurvedi 2006), low dissolved oxygen, and high organic matter loading (Sawhney 2008). The lower BOD values recorded during winter can be associated with low decomposition rate due to low temperature, high dissolved oxygen concentration and reduced microbial activity (Sachidanandamurthy, Yajurvedi 2004). Bashir et al. (2017) observed that the BOD in Anchar Lake ranged from 2.52 to $7.2 \mathrm{mg} \mathrm{L}^{-1}$ with a mean value of $4.86 \mathrm{mg} \mathrm{L}^{-1}$ and described this range of BOD as an indicator of pollution.

Ammonia concentration was observed to change from $0.07 \mathrm{mg} \mathrm{L}^{-1}$ in July 2016 at site A1 to $0.32 \mathrm{mg} \mathrm{L}^{-1}$ in January 2018 at site A2 with a mean value of $0.17 \pm 0.05 \mathrm{mg} \mathrm{L}^{-1}$. The ammonia concentration was higher during winter and lower during summer. The high ammonia concentration during winter can be due to less macrophytic growth that consumes ammonia. The low ammonia recorded during spring and summer is associated with photosynthetic assimilation of ammonia by autotrophs to attain maximum growth. The results are in agreement with other findings (Naik et al. 2015). Bashir et al. (2017) reported that ammonia nitrogen in Anchar Lake ranged from 0.05 to $0.17 \mathrm{mg} \mathrm{L}^{-1}$ with a mean value of $0.11 \mathrm{mg} \mathrm{L}^{-1}$, while Tehseen et al. (2018) observed that ammonia nitrogen in Anchar Lake ranged from 0.231 to $0.381 \mathrm{mg} \mathrm{L}^{-1}$ with a mean value of $303 \mathrm{mg} \mathrm{L}^{-1}$.

Iron concentration in lake water fluctuated from 0.12 $\mathrm{mg} \mathrm{L}^{-1}$ in February 2017 at site $\mathrm{A} 1$ to $0.28 \mathrm{mg} \mathrm{L}^{-1}$ in August 2017 at site A2 with a mean value of $0.18 \pm 0.04 \mathrm{mg} \mathrm{L}^{-1}$. High iron concentration of iron occurred during summer due to higher organic loading into the lake (Lund 1965). Corroded iron pipes also can be a source of iron in water (Sarin et al. 2004). Decline in oxygen concentration could be the reason for elevated iron content in water bodies during summer (Jumppanen 1976). Tehseen et al. (2018) observed that iron concentration in Anchar Lake ranged from 0.690 to $0.908 \mathrm{mg} \mathrm{L}^{-1}$ with a mean value of $0.724 \mathrm{mg}$ $\mathrm{L}^{-1}$.

\section{Macroinvertebrate fauna}

Prior to the current study, macroinvertebrate fauna of Anchar lake was investigated by Bashir et al. (2017). Eighteen taxa were reported in the study representing 12 arthropod species, three annelids and three molluscs. Abubakr et al. (2018) recorded three macroinvertebrate taxa from Anchar Lake: Limnodrilus hoeffmeisteri, Erpobdella octoculata and Glassophonia complanata. During present study, a total of 20 macroinvertebrate taxa, belonging to 
Table 2. The systematic list and species composition of macroinvertebrates in Anchar Lake

\begin{tabular}{|c|c|c|c|c|c|c|c|}
\hline Phylum & Class & Order & Family & Genus, species & Site A1 & Site A2 & Site A3 \\
\hline \multirow[t]{4}{*}{ Annelida } & \multirow[t]{2}{*}{ Hirudinea } & Rhynchobdellida & Glossiphonidae & Hirudo sp. & + & + & - \\
\hline & & Pharyngobdellida & Erpobdellidae & Erbobdella sp. & + & + & + \\
\hline & \multirow[t]{2}{*}{ Oligochaeta } & \multirow[t]{2}{*}{ Haplotoxida } & \multirow[t]{2}{*}{ Tubificidae } & Limnodrilus sp. & + & + & + \\
\hline & & & & Tubifex sp. & + & + & + \\
\hline \multirow[t]{12}{*}{ Arthropoda } & \multirow[t]{11}{*}{ Insecta } & \multirow[t]{4}{*}{ Diptera } & Chironomidae & Chironomus sp. & + & + & + \\
\hline & & & Ceratopgonidae & Bezzia sp. & - & - & + \\
\hline & & & Simulidae & Simulium sp. & - & - & + \\
\hline & & & Tipulidae & Tipula sp. & - & - & + \\
\hline & & Odonata & Coenagrionoidea & Enallagma sp. & + & + & + \\
\hline & & Plecoptera & Perlidae & Acroneuria sp. & - & - & + \\
\hline & & Trichoptera & Limniphilidae & Limniphilus sp. & - & - & + \\
\hline & & Ephemeroptera & Baetidae & Baetis sp. & + & + & + \\
\hline & & Coleoptera & Dytisicidae & Coptotomus sp. & + & - & + \\
\hline & & \multirow[t]{2}{*}{ Hemiptera } & Corixidae & Corixa sp. & + & + & + \\
\hline & & & Gerridae & Gerris sp. & - & - & + \\
\hline & Maxillopoda & Amphipoda & Gammaridae & Gammarus sp. & + & + & + \\
\hline \multirow[t]{4}{*}{ Molluscs } & \multirow[t]{2}{*}{ Gastropoda } & \multirow[t]{2}{*}{ Basommatophora } & \multirow[t]{2}{*}{ Lymnaeidae } & Lymnaea auricularia & + & + & + \\
\hline & & & & Lymnaea stagnalis & + & + & + \\
\hline & \multirow[t]{2}{*}{ Bivalvia } & \multirow[t]{2}{*}{ Veneroida } & Corbiculidae & Corbicula sp. & + & - & - \\
\hline & & & Sphaeriidae & Sphaerium sp. & + & + & - \\
\hline
\end{tabular}

three major phyla (Annelida, Arthropoda and Mollusca), were recorded from the three study sites in Anchar Lake. The recorded macroinvertebrate taxa belonged to six classes, 13 orders and 18 families, of which 12 families belonged to Arthropoda, three to Annelida and three to Mollusca. The systematic list of and species composition of macroinvertebrates recorded during the current study from Anchar Lake is given in Table 2.

\section{Population density of macroinvertebrates}

The total population density of macroinvertebrate fauna at site A1 was estimated to be 6689 individuals per $\mathrm{m}^{2}$ (Table 3), with the range in population density between 15 individuals per $\mathrm{m}^{2}$ in December 2017 and 666 individuals per $\mathrm{m}^{2}$ in June 2016 (Fig. 2). The relative contribution of arthropods was $42 \%$ with 2839 individuals per $\mathrm{m}^{2}$, followed by annelids with relative contribution of $36 \%$ with 2377 individuals per $\mathrm{m}^{2}$. The relative contribution of molluscs was estimated to be $22 \%$ with 1473 individuals per $\mathrm{m}^{2}$ (Fig. 3).

The total population density of macroinvertebrate fauna at site A2 was estimated as 6783 individuals per $\mathrm{m}^{2}$ (Table 4), which fluctuated from 59 individuals per $\mathrm{m}^{2}$ in January 2018 to 593 individuals per $\mathrm{m}^{2}$ in June 2017 (Fig. 2). The relative contribution of annelids was $41 \%$ with 2745 individuals per $\mathrm{m} 2$. The relative contribution of arthropods was $38 \%$ with 2609 individuals per $\mathrm{m}^{2}$. The relative contribution of molluscs was $21 \%$ with 1429 individuals per $\mathrm{m}^{2}$ (Fig. 4)

The total population density of macroinvertebrate fauna at site A3 was 7395 individuals per $\mathrm{m}^{2}$ (Table 3), fluctuating from a population density of 119 individuals per $\mathrm{m}^{2}$ in

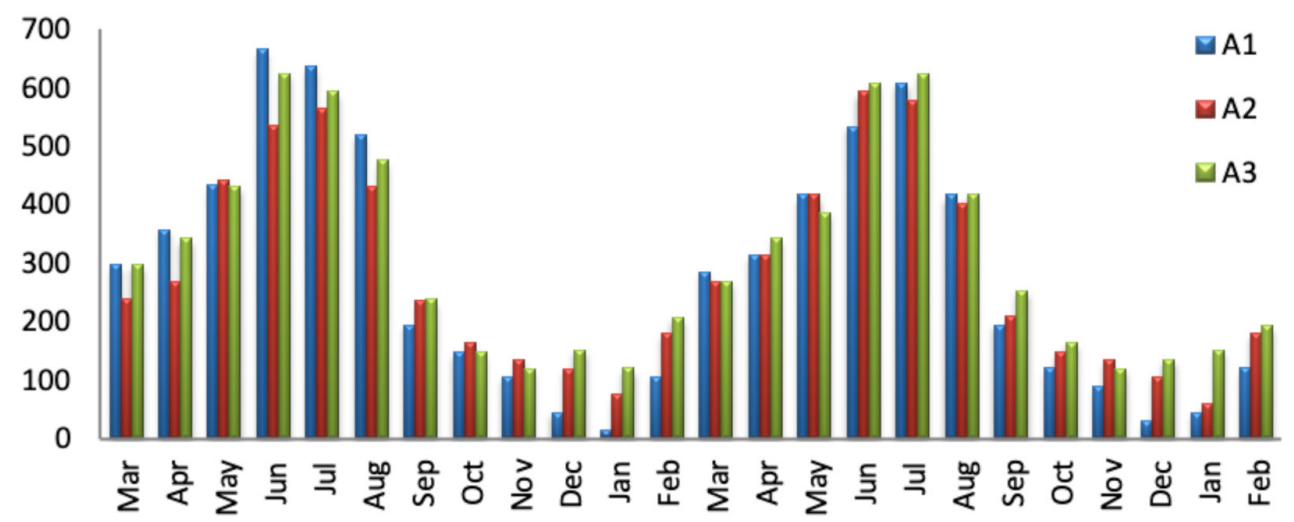

Fig. 2. Monthly fluctuation in population density (individuals per m2) of macroinvertebrates at different study sites in Anchar Lake. 
Table 3. Mean population density (individuals per $\mathrm{m}^{2}$ ), number of individuals and contribution of different macroinvertebrate phyla in Anchar Lake

$\begin{array}{lccccccc}\text { Phylum } & \text { Site A1 } & \text { Site A2 } & \text { Site A3 } & \begin{array}{c}\text { Mean population } \\ \text { density }\end{array} & \begin{array}{c}\text { Total nomber of } \\ \text { individuals }\end{array} & \begin{array}{c}\text { Contribution } \\ \text { (\%) }\end{array} \\ \text { Arthropoda } & 2839 & 2609 & 3599 & 3015.67 & 9047 & 43.35 \\ \text { Annelida } & 2377 & 2745 & 2828 & 2650.00 & 7950 & 38.10 \\ \text { Mollusca } & 1473 & 1429 & 968 & 1290.00 & 3870 & 18.55 \\ \text { Total } & 6689 & 6783 & 7395 & 6955.67 & 20867 & 100\end{array}$

November 2016 to 622 individuals per $\mathrm{m}^{2}$ in June 2016 and July 2017 (Fig. 2). The relative contribution of arthropods was $49 \%$,with 3599 individuals per $\mathrm{m}^{2}$, followed by annelids with $38 \%$ and 2828 individuals per $\mathrm{m}^{2}$ and molluscs with $13 \%$ and 968 individuals per $\mathrm{m}^{2}$ (Fig. 5).

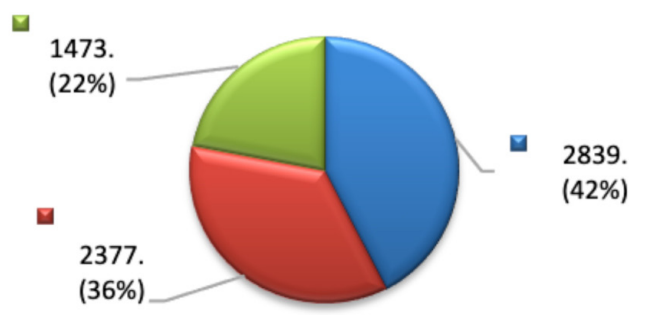

\section{$\square$ A1 Arthropods $\square$ A1 Annelids $\square$ A1 Molluscs}

Fig. 3. Total population density (individuals per $\mathrm{m}^{2}$ ) and percent contribution of arthropods, annelids and molluscs at site A1 in Anchar Lake.

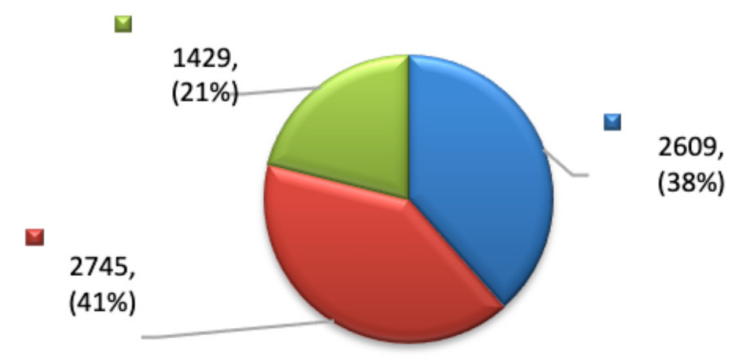

\section{$\square$ A2 Arthropods $\square$ A2 Annelids $\square$ A2 Molluscs}

Fig. 4. Total population density (individuals per $\mathrm{m}^{2}$ ) and percent contribution of arthropods, annelids and molluscs at site A2 in Anchar Lake.

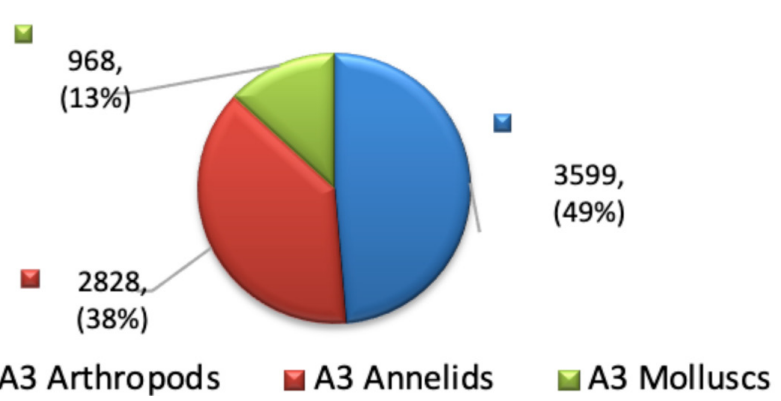

Fig. 5. Total population density (individuals per $\mathrm{m}^{2}$ ) and percent contribution of arthropods, annelids and molluscs at site A3 in Anchar Lake.
A total of 20867 individuals of macroinvertebrates were recorded from Anchar Lake, of which arthropods comprised 9047 individuals, annelids comprised 7950 individuals and molluscs comprised 3870 individuals. The mean population density of macroinvertebrate fauna in Anchar was estimated to be 6956 individuals per $\mathrm{m}^{2}$. Arthropods were found to be dominant over annelids and molluscs. The contribution of arthropods was $43.36 \%$ with a mean population density of approximately 3016 individuals per $\mathrm{m}^{2}$. The contribution of annelids was $38.10 \%$ with a mean population density of 2650 individuals per $\mathrm{m}^{2}$. The contribution of molluscs was estimated $18.55 \%$ with a mean population density of 1290 individuals per $\mathrm{m}^{2}$ (Table 3 ).

Biological indices employed exhibited marked variation at different study sites during the investigation period. The Shannon-Wiener diversity index $(H)$ was $2.40,2.14$ and 2.39 at sites $\mathrm{A} 1, \mathrm{~A} 2$ and $\mathrm{A} 3$, respectively, with a mean value of 2.31. The Simpson's diversity index $(1-D)$ was $0.89,0.86$ and 0.88 at sites $\mathrm{A} 1, \mathrm{~A} 2$ and $\mathrm{A} 3$, respectively, with a mean value of 0.87 . The Margalef's species richness index $(D)$ was $1.47,1.22$ and 1.76 at sites A1, A2 and A3, respectively, with a mean value of 1.58 . Species evenness $(E)$ was $0.18,0.19$ and 0.15 at sites $\mathrm{A} 1, \mathrm{~A} 2$ and $\mathrm{A} 3$, respectively, with a mean value of 0.17 (Fig. 6).

A relatively large diversity of macroinvertebrates occurred in Anchar Lake, due to the standing nature of water (Pamplin et al. 2006; Petrovici et al. 2010), abundant macrophytic growth that offers a great array of microhabitats and suitable breeding sites to macroinvertebrates (Tolonen et al. 2003; Petrovici et al. 2010; Elipek et al. 2010), and

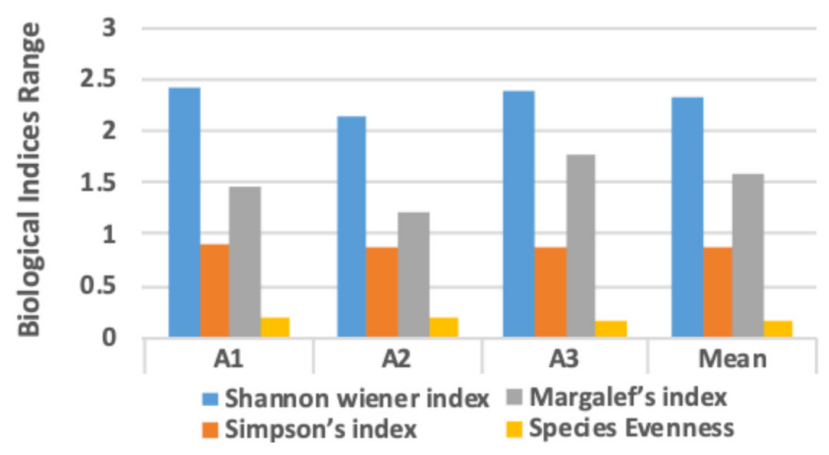

Fig. 6. Diversity, richness and evenness of macroinvertebrates in Anchar Lake. 
decomposed organic matter that maintains favourable benthic conditions for the growth of macroinvertebrate fauna (Elipek et al. 2010). However, compared to other lentic ecosystems of Kashmir, primarily Dal Lake, the macroinvertebrate diversity in Anchar Lake showed a noticeable decline, which may be attributed to deteriorated water quality as a result of maximum anthropogenic pressure coupled with sedimentation, soil erosion and human intervention on lakes like bathing, washing and other recreational activities (Dinakaran, Aabalagan 2007). Sedimentation reduces suitability of benthic conditions and resources for macroinvertebrates, which results in declining diversity of macroinvertebrates (Gammon 1970). Poor water quality is also responsible for declining macroinvertebrate diversity, as pollution sensitive taxa begin to disappear and become replaced by pollution tolerant taxa (Ngodhe 2014; Bashir et al. 2018).

Peak values of population density of macroinvertebrates were observed during summer. The summer maxima of macroinvertebrate diversity and density may be due to high temperature (Ibanez et al. 2002), elevated rate of organic matter decay and deposition (Pamplin et al. 2006; Elipek et al.2010), decreased water depth (Arab et al.2004), and death and decay of macrophytes creating suitable conditions for benthic macroinvertebrates (Dutta, Malhotra 1986), and to dense macrophytic growth, which provide food, accommodation and suitable breeding places (Kouame et al. 2011). The sharp decrease in density of macroinvertebrate fauna during winter may be due to winter precipitation coupled with enhanced loading of suspended solids causing dislodgement of macroinvertebrate fauna due to instability of substrate (George et al. 2010) and higher water depth (Arab et al. 2004).

Anchar Lake, being almost uniformly polluted at all the three investigated sites, reflected similar population density of macroinvertebrates. However, higher density was registered at site A3 (7395 individuals per $\mathrm{m}^{2}$ ), compared to other sites (6689 individuals per $\mathrm{m}^{2}$ at $\mathrm{A} 1$ and 6783 individuals per $\mathrm{m}^{2}$ at $\mathrm{A} 2$ ), due to appearance of pollution sensitive taxa (as Acroneuria sp.) during winter, in addition to other species. Less disturbance and less urbanization impact at site $\mathrm{A} 1$ is responsible for the presence of pollution sensitive taxa. In Dal Lake, higher population density of macroinvertebrates was observed at an undisturbed site as compared to a disturbed site (Habib,Yousuf 2013; Mushtaq et al. 2014). The abundance of pollution-tolerant species, mostly Limnodrilus hoffmeisteri, Tubifex tubifex, Chironomus sp., and Lymnaea sp. in Anchar Lake, especially at site A2, indicates organic pollution and eutrophication. The results are similar to findings in other studies (Oliver 1971; Brinkhurst, Cook 1974; Milbrink 1980; Timm et al. 2001; Khan et al. 2007. The occurrence of Limnodrilus hoffmeisteri and Erpobdella octoculata at high density was attributed to presence of organic-rich waters and sewage loading in Anchar Lake, which had positive effect on growth of these worms (Gojar, Abubakr 2017). The study also concluded that higher concentration of nitrate nitrogen, phosphorus, free carbon dioxide and hypoxic conditions in the lake positively favoured the growth of these worms, which are indicators of poor water quality. The abundance of chironomids also signifies organic pollution (Bay et al. 1966; Kaushik et al. 1991) and low oxygenated water (Custodio et al. 2018) and these species have been considered to be potential pollution indicator species (Milbrink 1980).

The lower values of species diversity and richness indices at site A2 may be due to maximum anthropogenic pressure (Olomukoro 2008) and poor water quality (Erimoro et al. 2007) at this site. Decline in diversity of macroinvertebrates with increasing trophic status was observed in Donghu Lake in China (Gong, Xie 2001). Diversity indices also indicate the pollution status of the water body. A species diversity index value above 3 indicates clean water and values between 1.0 to 3.0 show moderate pollution, and between 0 to 1.00 - heavy pollution (Willhm, Dorris 1966). Thus, Anchar Lake can be characterized as a moderately polluted water body. Clean and healthy aquatic ecosystems generally have high diversity, but small numbers of individuals per species, and water bodies with poor water quality have lower diversity but large number of individuals (Cairns et al. 1971). Higher species richness has been correlated with quality of a of waterbody (Somasheker, Ramaswamy 1984). In comparison, average diversity indices in Dal Lake were: Shannon diversity index 2.1 and evenness index 0.5 (Habib, Yousuf 2016).

\section{Correlation between physico-chemical and biological parameters}

Pearson's correlation coefficients between physicochemical and biological parameters are presented in Table 4. Abundance of annelids, arthropods and molluscs showed significant positive correlation with physicochemical parameters like temperature, chloride concentration, $\mathrm{BOD}$, and $\mathrm{pH}$, and negative correlation with dissolved oxygen concentration (Table 4). Higher temperature and rate of organic matter decomposition make the lake bottom favourable for growth of pollution-tolerant macroinvertebrate fauna (Elipek et al. 2010).

Further, high BOD is correlated with low dissolved oxygen content, as at low concentration of $\mathrm{DO}$, pollutionsensitive species are unable to survive and are replaced by pollution-tolerant macroinvertebrates. With higher load of nutrients and elevated BOD, other macroinvertebrates including Diptera, Odonata, Hemiptera, Coleoptera and Planorbidae decline (Tamiru et al 2017). Positive correlation of abundance of non-insect species, particularly annelids and molluscs with elevated nutrient level was shown in other studies (Sultana, Kala 2012; Tamiru et al. 2017). Positive correlation of abundance of annelids, arthropods and molluscs with nitrate, total phosphorus, and chloride 
Table 4. Correlation $(r)$ between physicochemical and biological parameters

$\begin{array}{lccc}\text { Chemical parameter } & \text { Annelids } & \text { Arthropods } & \text { Molluscs } \\ \text { Air temperature } & 0.849 & 0.842 & 0.778 \\ \text { Water temperature } & 0.847 & 0.837 & 0.766 \\ \text { Nitrate concentration } & 0.444 & 0.392 & 0.243 \\ \text { Total phosphorus concentration } & 0.418 & 0.356 & 0.214 \\ \text { Chloride concentration } & 0.808 & 0.799 & 0.732 \\ \text { BOD } & 0.705 & 0.707 & 0.63 \\ \text { pH } & 0.83 & 0.841 & 0.826 \\ \text { DO } & -0.548 & -0.76 & -0.39\end{array}$

concentration, $\mathrm{BOD}$, and $\mathrm{pH}$ and their negative correlation with dissolved oxygen concentration was shown in other studies (Milbrink 1973). The positive and highly significant correlation of temperature, total phosphorous concentration and BOD with macroinvertebrate abundance was found in Andean wetlands of Junin region, Peru (Custodio et al.2018). Excess of chlorides in lake water indicates organic pollution that favours abundance of pollution-tolerant species like Limnodrilus hoeffmeisteri, Tubifex tubifex, Chironomus sp. The results are similar with those from other studies (Brinkhurst, Cook 1974; Milbrink 1980). The distribution of Limnodrilus hoeffmeisteri and Erpobdella octoculata (Annelids) in Anchar Lake was greatly influenced by nitrate and phosphorus concentration in the lake and there was a positive correlation of abundance of these species with nitrate nitrogen and phosphorus concentration (Gojar, Abubakr 2017). In addition, Limnodrilus sp. abundance was found to show strong negative correlation with dissolved oxygen.

\section{Conclusions}

Results of the physicochemical analysis of Anchar Lake clearly show that there has been a continuous increase in alkalinity, $\mathrm{pH}$, total hardness, conductivity, chlorides, nitrates, total phosphorus and BOD in lake waters with time, together with a continuous decrease in transparency, water depth and DO. As a result, Anchar Lake is becoming more polluted, more eutrophic and is in an ecologically unstable state, which may have brought the lake to the verge of population extinction. Anchar Lake, which was once considered as a hub of biological diversity and was worldly known for its pristine and crystal clear waters, now witnesses a decline in biodiversity. The dominance of pollutiontolerant macroinvertebrate taxa clearly indicate organic pollution stress and eutrophication of the lake. Constantly increasing anthropogenic pressure, including sewage input, waste dumping, agricultural input, influx of toxic wastes into lake, illegal encroachments at the lake periphery and above all negligence of concerned government authorities are the main causes behind devastation of Anchar Lake.

\section{Acknowledgements}

Author expresses gratitude to Dr. Mohammad Farooq Mir (Head Hydrobiology Research Laboratory, Govt. S.P College, Cluster University, Srinagar, Kashmir for his constant whole hearted guidance and encouragement throughout the Research program.

\section{References}

Adoni A.D. 1985. Work Book of Limnology. Pratibha Publication, Sagar.

Ahangar I.A. 2014. Physico-chemical characteristics of Anchar Lake Srinagar with reference to plankton, primary productivity and fisheries. Thesis, Jiwaji University, Gwalior.

Ahangar I.A., Saksena D.N., Mir M.F., Ahangar M.A. 2012. Seasonl variation in physico-chemical characteristics of Anchar Lake Srinagar, Srinagar, Kashmir. Int. J. Adv. Biol. Res. 3: 352-357.

Ahangar I.A., Saksena, D.N., Mir M.F. 2012. Limnological studies, assessment of nutrients, trophic status and major threats to Anchar Lake, Kashmir. Int. J. Sci. Knowl. 1: 3-16.

Akthar A., Parveen M., Qayoom I. 2015. Limnological features of Dal Lake of Kashmir valley with special reference to the anthropogenic pressure along its water shed. Ecol. Environ. Conserv. 21: 497-803.

Ali U. 2014. Stress of environmental pollution on zooplanktons and their comparative studies in Dal Lake, Wular lake Ancharlake and Manasbal Lake, in Srinagar, Kashmir. Int. J. Eng. Sci. 3: 39-44.

Ali U. 2015. Impact of anthropogenic activates on Dal Lake (ecosystem/conservation strategies and problems). Int. J. $u$ - $e$ Serv. Sci. Technol. 8: 379-384.

APHA. 2004. Standard Methods for the Examination of Water and Waste Water. $20^{\text {th }}$ Ed. American Public Health Association, Washington.

Arab A., Lek S., Lounaci A., Park Y.S. 2004. Spatial and temporal patterns of benthic invertebrate communities in an intermittent river (North Africa). Ann. Limnol. 40: 317-327.

Arimoro F.O., Ikomi R.B., Efemuna E. 2007. Macroinvertebrate community patterns and diversity in relation to water quality status of river Ase, Niger Delta, Nigeria. J. Fisher. Aquat. Sci. 2: $337-344$.

Aura C.M., Raburu P.O., Hermann J. 2011. Macroinvertebrate community structure in rivers Kipkaren and Sosiani, River Nzoia basin, Kenya. J. Ecol. Nat. Environ. 3: 39-46.

Ayoade A.A., Fagade S.O., Adebisi A.A. 2006. Dynamics of 
limnological features of two manmade lakes in relation to fish production. African J. Biotechnol. 5: 1013-1021.

Baig S.A., Mahmood Q., Nawab B., Hussain A., Nafees M. 2010. Assessment of seasonal variations in surface water quality of ChitralRiver, North West frontier province (NWFP), Pakistan. World Appl. Sci. J. 9: 674-680.

Bashir A., Gupta A., Aziz R. 2018. Macroinvertebrates of Dal lake: An effort to assess the diversity, abundance, population density and trophic status. Int. J. Theor. Appl. Sci. 10: 117-125.

Bashir M., Chauhan R., Khan S, Mir F.M., Amin N. 2016. Macrozoobenthic community as biological indicators of pollution in Anchar Lake of Kashmir. Int. J. Curr. Res. 8: 26994-26999.

Bashir M., Chauhan R., Khan S., Mir F.M. Ashraf M., Amin N. 2017. Impact of anthropogenic pressure on the water quality of Anchar Lake in Kashmir. J. Chem. Biol. Phys. Sci. 7: 91-96.

Baur K.E., Pringle C.M. 2000. Special problems of urban river conservation: the encroaching megalopolis. In: Boon, P.J., Davies, B.R., and Petts, G.E. (eds) Global Perspectives on River Conservation: Science, Policy, and Practice. John Wiley and Sons, Chichester, pp. 385-401.

Bay E.C., Ingham A.A., Anderson L.D. 1966. Physical factors influencing chironomids infestation of water spreading basins. Ann. Entomol. Soc. Am. 59: 714-717.

Bhat S.A., Dar, G.A., Sofi A.H., Dar N.A., Pandit A.K. 2012. Macroinvertebrate community associations on three different macrophytic species in Manasbal Lake. Res. J. Environ. Sci. 6: 62-76.

Bhat S.A., Rather G.A., Pandit A.K. 2001. Impact of effluents from SKIMS, Soura on Ancharb lake. J. Res. Dev. 1: 31-38.

Bhatt L.R., Lacoul P., Lekhak H.D., Jha P.K. 1999. Physicochemical characteristics and phytoplankton of Taudaha Lake, Kathmandu. Pollut. Res. 18: 353-358.

Bhowmick B.N., Singh A.K. 1985. Phytoplankton population in relation to physic-chemical factors of River Ganga at Patna. Indian J. Ecol. 12: 360-364.

Borror D.J., Delongdwilight M., Triplehorn, C.A. 1976. An Introduction to the Study of Insects. $4^{\text {th }}$ Ed. Holt, Rinehart and Winston.

Brinkhurst R.O., Cook D.G. 1974. Benthic macroinvertibrates in relation to water and sediment chemistry. Freshwat. Biol. 4: 183-191.

Burton T.M., Turner R.R., Harris, R. C. 1977. Suspended and dissolved solids exported from three north Florida watersheds in contrasting land use. In: Correll D.L. (ed) Watershed Research in Eastern North America. Smithsonian Institution, Washington, pp. 323-342.

Cairns J.Jr., Dickson K.L. 1971. A simple method for the biological assessment of the effects of waste discharges on aquatic bottom-dwelling organisms. J. Water Pollut. Contr. Feder. 43: 755-772.

Chapman D. 1992. Water Quality Assessments - A Guide to Use of Biota, Sediments and Water in Environmental Monitoring. $2^{\text {nd }}$ Ed. Chapman \& Hall, Cambridge.

Chapman L.J., Scheider K.R., Apodaca, C.,Chapman C.A. 2004. Respiratory ecology of macroinvertebrates in a swamp-river system of East Africa. Biotropica 36: 572-585.

Custodio M., Chaname F., Pizarro S., Cruz D. 2018. Quality of aquatic environment and diversity of benthic macroinvertebrates of high Andean wetlands of the Junin region, Peru. Egypt. J. Aquat. Res. 44: 195-202.

Dalpatia B.D. 1998. Studies on ecology and population dynamics of zooplankton of some sub-tropical ponds of Jammu. Ph.D. thesis, University of Jammu, Jammu.

Dinakaran S., Aabalagan S. 2007. Anthropogenic impacts on aquatic insects in six streams of south Western Ghats. J. Insect Sci. 7: 37-42.

Duda A.M., Lenat D.R., Penrose D.L. 1982. Water quality in urban streamswhat we can expect. J. Water Pollut. Contr. Feder. 54: 1139-1147.

Dunn D.R. 1954. Notes on the bottom fauna of twelve Danish lakes. Vidensk. Medd. Dansk Naturh. Foren. 116: 251-268.

Dutta S.P.S., Malhotra Y.R. 1986. Seasonal variations in the macrobenthic fauna of Gadigarh stream (Miran Sahib) Jammu. Indian J. Ecol. 113: 138-145.

Edmonson W.T. 1959. Freshwater Biology. John Wily and Sons, New York, London.

Egborge A.B.M. 1994. Water Pollution in Nigeria; Biodiversity and Chemistry of Warri River. Ben Miller Books Nigeria Limited.

Elipek B.C., Arslan N., Kirgiz T., Oterler. B., Guher H., Ozkan N. 2010. Analysis of benthic macroinvertebrates in relation to environmental variables of Lake Gala, a National Park of Turkey. Turkish J. Fisher. Aquat. Sci. 10: 235-243.

Fishar M.R., Williams W.P. 2006. A feasibility study to monitor the macroinvertebrate diversity of the River Nile using three sampling methods. Hydrobiologia 556: 137-147

Gammon J.R. 1970. The Effect of Inorganic Sediment on Stream Biota. Water Pollution Control Research Series No. 18050 DWC, U.S. Environmental Protection Agency, Washington.

Gasim M.B., Toriman M.E., Rahim S.A., Islam M.S., Chek T.C., Juahir H. 2006. Hydrology and water quality and land use assessment ofTasik Chini Feeder Rivers, Pahang Malaysia. Geografia 3: 1-16.

Gaston K.J., Spicer J.I. 2004. Biodiversity: an Introduction. Blackwell Publishing.

George A.D.I., Abowei J.F.N., Alfred-Ockiya J.F. 2010. The distribution, abundance and seasonality of benthic macro invertebrate in Okpoka Creek sediments, Niger Delta, Nigeria. Res. J. Appl. Sci. Eng. Technol. 2: 11-18.

Gochhait B.C. 1991. Studies on limnological factors of river Buddhabalanga at Baripada (Orissa). Ph.D. thesis, Bhagalpur University, India.

Gojar A.A., Abubakr A. 2017. Distribution of benthic macroinvertebrates (Annelida; oligochaeta) in relation to water quality of Anchar Lake. MSc. Thesis. SKUAST, Kashmir.

Gong Z., Xie P., Wang S. 2000. Macrozoobenthos in two shallow, mesotrophic Chinese lakes with contrasting sources of primary production. J. North Am. Benthol. Soc. 19: 709-724.

Gong. Z., Xie P. 2001. Impact of eutrophication on biodiversity of the macrozoobenthos community in a Chinese shallow lake. J. Freshwater Ecol. 16: 171-178.

Gudoo M.Y. 2019. Diversity of macroinvertebrates in lentic water bodies of Kashmir, J \& K, India. Ph.D Thesis, Barkatullah University, Bhopal, M. P.

Gudoo M.Y. 2020. Macroinvertebrate population dynamics of an urban lentic ecosystem of Kashmir Himalaya. Int. J. Modern Plant Anim. Sci. 7: 33-48.

Gudoo M.Y., Mir M.F., Gupta A. 2017. Diversity, distribution and abundance of macroinvertebrates in Anchar Lake, Srinagar, Kashmir, J \& K, India. Int. J. Curr. Res. 9: 52390-52396.

Gundacker C. 2000. Comparison of heavy metal bioaccumulation in freshwater mollusks of urban river habitats in Vienna. Environ. Pollut. 110: 61-71.

Habib S., Yousuf A.R. 2013. Influence of harvesting on associated 
macrofaunal community of Hazratbal Basin of Dal Lake in Kashmir Himalayas. Int. J. Adv. Res. 1: 142-147.

Habib S., Yousuf A.R. 2016. Phytophilous macroinvertebrate community of an eutrophic lake in Kashmir Himalayas. J. Entom. Zool. Stud. 4: 318-325

Hoffsten P.O., Malmqvist. B. 2000. The macroinvertebrate fauna and hydrogeology of springs in central Sweden. Hydrobiologia 436: 91-104.

Ibanez A.A.L., Garcia-Calderon J.L., Perez-Rojas A., Alvarezhernandez S., Alvarez-Silva C., Nunez-Portugal E. 2002. El Lago de Metztitlán, Hidalgo. In: De La Lanza G., García-Calderón J.L. (eds) Lagos y Presas de México. Ed. AGT, México, D. F., pp. 253-268.

Jeelani M., Kaur H. 2014. Comparative studies on zooplankton in Dal Lake, Kashmir, India. J. Acad. Industr. Res. 2: 534-537.

Johnson R.K., Wiederhom T., Rosenberg D.M. 1993. Freshwater biomonitoring using individual organisms, populations and species assemblages of benthic macroinvertebrates. In: Rosenberg D.M., Resh V.H. (eds) Freshwater Biomonitoring and Benthic Macroinvertebrates. Chapman \& Hall.

Johnson B., Tuomori D., Sinha R. 1999. Impacts of on-site sewage systems and illicit discharges on the Rouge River. In: Proceedings of the National Conference "Retrofit Opportunities for water Resources Protection Urban Environment". EPA/625/R-99/002. EPA, Washington, pp. 132-135.

Jones R.C., Clark C.C. 1987. Impact of watershed urbanization on stream insect communities. Water Resour. Bull. 23: 10471055.

Jumppanen K. 1976. Effects of waste waters on a lake-ecosystem. Ann. Zool. Fenn. 13: 85-138.

Kak A.M. 2012. Anchar Lake on death bed. Greater Kashmir.

Karr J.R. 1995. Protecting aquatic ecosystems: clean water is not enough. In: Davis, W.S., Simon T.P. (eds) Biological Assessment and Criteria. Lewis Publishers, London, pp. 7-13.

Kaul V., Handoo J.K., Raina R. 1980. Physico-chemical characteristics of Nilnag- A high altitude forest lake in Kashmir and its comparison with the valley lakes. Proc. Indian Nat. Sci. Acad. 46: 528-541.

Kaushik S., Sharma S., Saksena D.N. 1991. Ecological studies of certain polluted lentic waters of Gwailor region with reference to aquatic communities, In: Shastree N.K. (ed) Current Trends in Limnology. Narender Publishing House, New Delhi, pp. 185-200.

Khan A.N., Kamal, D., Mahmud M.M., Rahman M.A., Hossain M.A. 2007. Diversity, distribution and abundance of benthos in Mouri River, Khulna, Bangladesh. J. Sust. Crop Prod. 2: 19-23.

Kora A. L., Sahato G.A., Lashari K.H. 2008. Fish diversity in relation to physico-chemical properties of Keenjhar lake (district thatta), Sindh, Pakistan. Res. J. Fish. Hydrobiol. 3: $1-10$.

Korai A.L., Sahato G.A., Lashari K.H., Arbani. 2008. Biodiversity in relation to physico-chemical properties of Keenjhar Lake (district Thatta), Sindh, Pakistan. Turkish J. Fish. Aqua. Sci., 8: 259-268.

Kotpal R.L. 2018-2019. Invertebrate Zoology. $11^{\text {th }}$ Ed. S.Chand and Co., New Delhi.

Kouame M.K., Dietoa M.Y., Edia E.O., Da Costa S.K., Ouattara A., Gourène G. 2011. Macroinvertebrate communities associated withmacrophyte habitats in a tropical man-made lake (Lake Taabo, Côted'Ivoire). Knowl. Manage. Aquat. Ecosyst. 400: 3-9.
Kovalenko K.E., Brady V.J., Ciborowski J.J.H., Ilyushkin S., Johnson L.B. 2014. Functional changes in littoral macroinvertebrate communities in response to watershed-level anthropogenic stress. PLoS One 9: e101499.

Lund J.W.G. 1965. The ecology of freshwater phytoplankton. Biol. Rev. 40: 231-293

Mahananda M.R., Mohanty B.P., Behera N.R. 2010. Physicochemical analysis of surface and ground water of Bargarh District, Orissa, India. Int. J. Res. Rev. Appl. Sci. 2: 284-295.

Malik A.Y., Ali M. 2012. Macrozoobenthos in the BOD-Dal basin of Dal Lake Kashmir, J and K, India. J. Industr. Pollut. 28: 131135.

Mangun W.R. 1989. A comparison of five northern Virginia watersheds in contrasting land use patterns. J. Environ. Syst. 18: 133-151.

Milbrink G. 1973. Oligochaetes and water pollution in two deep Norwegian lakes. Hydrobiologia 278: 213-222.

Milbrink G. 1978. Indicator communities of oligochaetes in Scandinavian lakes. Int. Verein. Theor. Angew. Limnol. Verh. 20: 2406-2111.

Milbrink G. 1980. Oligochaete communities in population biology; the European situation with rapid reference to lakes in Scandinavia. In: Brinkhurst R.O., Cook D.G. (eds) Aquatic Oligochaete Biology. Plenum Press, New York, pp. 433-455.

Moretti M.S., Callisto, M. 2005. Biomonitoring of benthic macroinvertebrates in the middle Doce River watershed. Acta Limnol. Brasil. 17: 267-281.

Mushtaq B., Rajni Raina R., Wanganeo A., Yousuf A.R., Jehangir A. 2014. Variations in macrozoobenthos communities with deweeding operations in Nishat basin of Dal Lake Srinagar, Kashmir. Amer. Int. J. Contemp. Sci. Res. 1: 1-8.

Naik G., Rashid M., Balkhi M.H. 2015. Changes in physicochemical parameters at different sites of Manasbal Lake of Kashmir, India. Fisher. Aquacult. J. 6: 1-4.

Naik S. 2009. Studies on pollution status of Bondamunda area of Rourkela industrial complex. Ph.D. thesis submitted to the National Institute of Technology, Rourkela.

Ngodhe S.O., Raburu P.O., Achieng A. 2014. The impact of water quality on species diversity and richness of macroinvertebrates in small water bodies in Lake Victoria basin, Kenya. J. Ecol. Nat. Environ. 6: 32-41

Ohle W. 1934. Die Bedeutung der Anstanschvorgange ZwischenSchlam und Wasser fur den Stoffkreislauf der Gewasser. Vom Wasser 13: 87-97.

Okeola FO., Kolawole O. D., Ameen O.M. 2010. Comparative study of physico chemical parameters of water from a river and its surrounding wells for possible interactive effect. $A d v$. Environ. Biol. 4: 336-340.

Olomukoro J.O. 2008. Factors influencing the benthic macrofauna of erosional biotope in Warri River, Nigeria. Biosci. Res. Comm. 20: 18-23.

Olsen S. 1950. Aquatic plants and hydrospheric factors 1. Aquatic plants in Swjutland, Denmark. Svensk Botanisk Tidskrift 44: $1-34$.

Otsuki A., Wetzel R.G. 1972. Coprecipitation of phosphates with carbonates in a Marl Lake. Limnol. Oceanogr. 17: 763-767.

Pamplin P.A.Z., Almeida T.C.M., Rocha O. 2006. Composition and distribution of benthic macroinvertebrates in Americana Reservoir (SP, Brazil). Acta Limnol. Brasil. 18: 121-132.

Paul M.J., Meyer J.L. 2001. Streams in the urban landscape. Annu. Rev. Ecol. Syst. 32: 333-365.

Pennak W.R. 1978. Freshwater Invertebrates of United States. Willey 
Interscience Publishing, New York.

Petrovici M., Balan M.S., Gruia R., Pop O.G. 2010. Diversity of macrozoobenthic community from fish farms as a consequence of the fisheries management. Environ. Eng. Manage. J. 9: 1589-1592.

Rosenberg D.M., Resh V.H. (eds) 1993. Freshwater Biomonitoring and Benthic Macroninvertehrates. Chapman and Hall, New York .

Sarin P., Snoey V.L., Bebee J., Jim K.K., Beckett M.A., Kriven W.M., Cement J.A. 2004. Iron release from corroded iron pipes in drinking water distribution system: effect of dissolved oxygen. Water Res. 38: 1259-1269.

Sawhney N. 2008. Biomonitoring of River Tawi in the vicinity of Jammu City. Ph.D. Thesis. University of Jammu, Jammu.

Sawyer C.H. 1960. Chemistry for Sanitary Engineers. McGraw Hill Book, New York.

Schenkova J., Helesic J. 2006. Habitat preferences of aquatic Oligochaeta (Annelida) in the Rokttna River, Czech Republic - a small highland stream. Hydrobiologia 564: 117-126.

Shinde S.E., Pathan T.S., Raut K.S., More, P.R., Sonawane D.L. 2010. Seasonal variations in physico-chemical characteristics of Harsool-Savangi Dam, District Aurangabad, India. Ecoscan 4: $37-44$

Shokri M., Rossaro B., Rahmani H. 2014. Response of macroinvertebrate communities to anthropogenic pressure in Tajan River (Iran). Biologia 69: 1395-1409.

Sinha M.P., Kumar R., Srivastava R., Mishra S.K., Choudhuri A.K. 2002). Ecotaxonomy and biomonitoring of lake for conservation and management. Biotic Profile In: Kumar A. (ed) Ecology and Conservation of Lakes, Reservoirs and Rivers. Vol. II. ABD Publication Jaipur. pp. 248-289

Somashekar R.K., Ramaswamy S.N. 1984. Biological Assesment of water pollution: a study of river Kapila. Int. J. Environ. Stud. 23: 261-267.

Sultana R., Kala D.S. 2012. Water body quality analysis by benthic macroinvertebrates. Int. J. Pharm. Biol. Sci. 2: 269-279.

Sushil M., Reshi J.M., Krishna M. 2014. To evaluate the water quality status and responsible factors for variation in Anchar
Lake, Kashmir. IOSR J. Environ. Sci. Toxicol. Food Technol. 8: $55-62$.

Tamiru S.M.,Asfaw S.L.,Yilma S.M.2017. Correlation study of some pgysico-chemical parametersand benthic macroinvertebrates metrics on the ecological impact of floriculture industries along Wedecha River Debrezeit, Ethiopia. J. Coast. Life Medic. 5: $433-440$

Tate C.M., Heiny J.S. 1995. The ordination of benthic invertebrate communities in the South Platte River Basin in relation to environmental factors. Freshwater Biol. 33: 439-454.

Tehseen A.A., Balkhi M.H 2018. Trophic status assessment of Anchar Lake, Kashmir. J. Pharmacogn. Phytochem. 7: 11541156.

Timm H., Mols T. 2001. Macrozoobenthos of Lake Vervi. Hydrobiologia 547: 185-195.

Tolonen K.T., Hamalainen H., Holopainen I.J., Mikkonen K., Karjalainen J. 2003. Body size and substrate association of littoral insects in relation to vegetation structure. Hydrobiologia 499: 179-190.

Umerfaruq Q.M., Solanki H.A. 2015. Physico-chemical parameters of water in Bibi Lake, Ahmedabad, Gujrat, India. J. Pollut. Effects Contr. 3: 134.

Vollenweider R. 1968. Scientific Fundamentals of the Eutrophication of Lakes and Flowing Waters, with Particular Reference to Nitrogen and Phosphorus as Factors in Eutrophication. OECD, Paris.

Vollenweider R. 1975. Input-output models with special reference to the phosphorus loading concept in limnology. Schweiz. Z. Hydrol. 37: 53-83.

Welch P.S. 1948. Limnological Methods. Blakiston, Philadelphia.

Wetzel R.G. 2001. Limnology: Lake and River Ecosystem. $3^{\text {rd }}$ Ed. Academic Press, London.

Wilhm J.L., Dorris T.C. 1966. Species diversity of benthic marcoinvertebrates in a stream receiving domestic and oil refinery effluents. Amer. Midl. Nat. 76: 427-449.

Zuber S.M. 2007. Ecology and economic valuation of Lake Mansar, Jammu. Ph.D. Thesis, University of Jammu, Jammu. 